\title{
PENGARUH IMPLEMENTASI SPOT BILL READING SYSTEM (SBRS) TERHADAP PENINGKATAN KINERJA OPERASIONAL PADA PT. XYZ
}

\author{
Nosa A'la Almasykuri Khaffach \\ Fakultas Ilmu Komputer, Universitas Bina Nusantara, Kemanggisan, Jakarta Barat, 11480, Indonesia \\ E-mail: nosa.khaffach@gmail.com
}

\begin{abstract}
Abstrak
Tujuan dari penelitian ini adalah untuk membuktikan bahwa terdapat pengaruh yang cukup signifikan dari implementasi Spot bill reading system (SBRS) terhadap Kinerja Operasional pada PT.XYZ. Metodologi penelitian yang digunakan adalah penelitian kuantitatif dengan teknik analisis data menggunakan Regresi Liniear Berganda. Proses pengumpulan data dilakukan melalui kuesioner. Hasil penelitian yang dicapai adalah diterimanya hipotesis terdapat pengaruh dari kemudahan penggunaan, akurasi data dan validasi data terhadap kinerja operasional perusahaan. Simpulan yang diperoleh adalah dengan pengimplementasikan Spot bill reading system (SBRS) dapat meningkatkan kinerja operasional perusahaan.
\end{abstract}

Kata Kunci: Spot bill reading system, Kemudahan penggunaan, Akurasi data, Validasi data.

\begin{abstract}
The purpose of this research is to prove that there is influence of the Implementation of Spot bill reading system (SBRS) through the Operational Performance on PT.XYZ. The research methodology is quantitative research with Multiplier Liniear Regression of data analysis. The process of collecting data through interviews and questionnaires. The result achived was the acceptance of the hypothess that there is the influence if ease of use, data accuracy and validation data on the performance of the company's operations. The conclusions obtained are the implementation of Spot bill reading system (SBRS) can boost the company's operational performance.
\end{abstract}

Keywords: Spot bill reading system, Ease of use, Data accuracy, Validation data.

\section{Pendahuluan}

Pesatnya perkembangan sistem informasi beberapa tahun belakangan ini menjadikannya sebagai kelebihan dalam bersaing (competitive advantage) yang wajib dimiliki oleh perusahaan untuk dapat memenangkan persaingan bisnis. Untuk itu, investasi sistem informasi untuk perusahaan haruslah direncanakan sebaik mungkin, supaya investasi yang dilakukan tidak sia-sia. Dengan demikian, perlu dianalisis keselarasan sistem informasi dengan strategi bisnis pada perusahaan tersebut. Pada dasarnya sistem informasi yang dilakukan haruslah mendukung strategi bisnis untuk mencapai tujuan bisnis perusahaan.

Dampak penerapan teknologi baru dan kepercayaan terhadap kinerja individu menemukan hasil bahwa kedua variabel tersebut memiliki pengaruh positif terhadap variabel kinerja individual [1].

PT. XYZ yaitu perusahaan swasta penyedia jasa air besih bagi area industri, area bisnis maupun pemukiman penduduk di wilayah operasional, meliputi Jakarta Timur, sebagian Jakarta Pusat dan Jakarta Utara. Perusahaan ini senantiasa berupaya memberikan pelayanan terbaik berupa jasa penyedia kebutuhan air bersih yang terjamin kualitas dan kuantitasnya. Perusahaan XYZ ini mendapat konsesi untuk melakukan usaha selama 25 tahun berdasarkan perjanjian kerjasama dengan Perusahaan Daerah Air Minum DKI Jakarta (PAM Jaya). Kerjasama ini berlaku efektif sejak tanggal 1 Februari 1998 hingga tanggal 31 Januari 2023.

Saat ini PT. XYZ sudah mengimplementasikan sistem informasi untuk mendukung proses operasional perusahaan tersebut. Spot bill reading system (SBRS) merupakan suatu sistem yang dapat digunakan oleh meter reader yaitu seorang karyawan perusahaan tersebut untuk dapat terjun ke lapangan operasional untuk mencatat kubikasi meter air pelanggan yang telah dikonsumsi oleh pelanggannya perbulan dan langsung mencetak tagihan pada saat itu juga untuk diserahkan kepada pelanggan tersebut, sehingga pelanggan tersebut dapat mengetahui 
jumlah yang harus dibayarkan untuk tagihan air bulan tersebut. Selain itu SBRS juga meliputi aplikasi berbasis Website dan PDA/Handheld untuk dibawa meter reader ke lapangan.

Teknologi informasi melalui komputerisasi dan sistem informasi yang terintegrasi akan sangat mendukung sistem informasi manajemen dalam sebuah perusahaan. Pemrograman komputer dapat bermanfaat untuk melakukan pengolahan data secara cepat, menyeragamkan dokumentasi, ketepatan penghitungan, dan menghindari pemasukan data yang berulang-ulang [2]. Dengan pemrograman komputer untuk beberapa pekerjaan yang berulang-ulang dapat mengurangi kemungkinan kesalahan dalam penginputan data. Karena apabila dengan penginputan secara manual dapat kemunkinan terjadinya kesalahan dari sumber daya manusianya.

Penelitian lain menunjukkan bahwa pemanfaatan RFID tidak harus dilihat oleh praktisi hanya sebagai biaya melakukan bisnis melainkan sebagai cara untuk meningkatkan efisiensi dan efektivitas yang pada akhirnya akan menyebabkan peningkatan keuntungan [3].

Teknologi informasi komunikasi telah meningkatkan jumlah informasi yang tersedia untuk individu. Kemampuan mereka untuk berbagi informasi tersebut jauh melampaui harapan semua orang sehingga masih banyak lagi manfaat yang di dapat dari informasi yang cepat dan akurat [4].

Kinerja (performance) merupakan gambaran mengenai tingkatan pencapaian pelaksanaan suatu kegiatan/program/kebijakan dalam mewujudkan sasaran, tujuan, misi dan visi perusahaan yang tertuang dalam strategic planning suatu organisasi [5].

Kinerja operasional berhubungan dengan operasi internal dari organisasi seperti produksi, kualitas produk dan kepuasan pelanggan [6]. Kinerja perusahaan mencakup kinerja perusahaan secara keseluruhan sehingga dihasilkan ukuran kinerja yang obyektif [7].

Hubungan sistem informasi dengan kinerja adalah individu pengetahuan IT dan kedua metode komunikasi tradisional dan elektronik secara signifikan berkontribusi pada kinerja proses internal perusahaan kecil, kinerja proses internal, organisasi TI pengetahuan, dan metode komunikasi elektronik mempengaruhi kinerja pelanggan, dan kinerja keuangan adalah dipengaruhi oleh proses dan kinerja pelanggan [8].

TIK memiliki pengaruh positif yang signifikan terhadap karakteristik pekerjaan karyawan, karyawan kurang puas dengan pekerjaan mereka dan memiliki kinerja yang lebih rendah setelah pelaksanaan TIK. Data kualitatif menunjukkan bahwa ada empat gaya kontekstual yang unik, yaitu hambatan lingkungan, kesulitan belajar, kejutan budaya, dan penilaian karyawan, yang kami percaya bertanggung jawab untuk kepuasan kerja yang lebih rendah dan performa kerja [9].

Spot bill reading system (SBRS) adalah suatu sistem informasi yang telah di implementasikan untuk mendukung proses operasional perusahaan XYZ. Spot bill reading system (SBRS) merupakan suatu sistem yang dapat digunakan oleh Meter Reader yaitu seorang karyawan perusahaan tersebut untuk datang ke lapangan operasional untuk mencatat kubikasi meter yang telah dikonsumsi oleh pelanggannya perbulan dan langsung mencetak tagihan pada saat itu juga untuk pelanggan.

Sistem tersebut berupa aplikasi berbasis website yang menyimpan data pelanggan, history pelanggan, pencatatan kubikasi meter, tagihan dan data keperluan operasional lainnya. Web Service digunakan untuk mengkaitkan berbagai aplikasi melalui Internet [7].



Gambar 1. Grandmap spot bill reading system.

Dari penjelasan sebelumnya, permasalahan yang akan di bahas dalam penelitan ini yaitu :

1. Apakah ada pengaruh kemudahan penggunaan sistem SBRS terhadap kinerja operasional perusahaan?

2. Apakah ada pengaruh akurasi data kubikasi sistem SBRS terhadap kinerja operasional perusahaan?

3. Apakah ada pengaruh validasi data kubikasi sistem SBRS terhadap kinerja operasional perusahaan?

Tujuan dari penulisan penelitian ini adalah :

1. Untuk dapat meningkatkan kinerja operasional perusahaan khususnya dalam implementasi sistem informasi SBRS.

2. Untuk membuktikan bahwa faktor kemudahan penggunaan, akurasi data dan validasi data dapat mempengaruh peningkatan kinerja operasional perusahaan. 
Manfaat dari penulisan penelitian ini adalah :

1. Manfaat bagi perusahaan

Hasil penelitian diharapkan dapat memberikan manfaat kepada perusahaan, agar dapat dijadikan masukan untuk strategi bisnis perusahaan dan pengambilan keputusan pada perusahaan tersebut. Dan untuk mengetahui apa saja yang harus diperhatikan dalam implementasi sistem informasi SBRS tersebut.

2. Manfaat bagi penulis

Hasil penelitian ini diharapkan dapat memberikan manfaat berupa tambahan pengetahuan kepada penulis mengenai pengaruh implementasi Spot bill reading system (SBRS) di PT. XYZ, khususnya pengaruh terhadap peningkatan kinerja operasional perusahaan.

3. Manfaat bagi pelanggan

Dari hasil penelitian ini diharapkan dapat meningkatkan pelayanan terhadap pelanggan. Agar dapat meningkatkan kepuasan pelanggan dengan adanya peningkatan kinerja operasional perusahaan tersebut.

Dalam penelitian ini terdapat 3 hipotesis yang akan digunakan dalam penelitian ini adalah sebagai berikut :

$\mathrm{H}_{1}$ : Ada pengaruh kemudahan penggunaan sistem SBRS terhadap kinerja operasional perusahaan.

$\mathrm{H}_{2}$ : Ada pengaruh akurasi data kubikasi sistem SBRS terhadap kinerja operasional perusahaan.

$\mathrm{H}_{3}$ : Ada pengaruh validasi data kubikasi sistem SBRS terhadap kinerja operasional perusahaan.

\section{Metodologi}

Penelitian ini dilaksanakan mulai bulan September 2011 dan diperkirakan akan selesai pada bulan Desember 2011. Dengan waktu penelitian tersebut diharapkan dapat mewujudkan hasil yang optimal sesuai dengan tujuan penelitian.

Dalam hal ini, peneliti melakukan penelitian di PT.XYZ yaitu perusahaan swasta penyedia jasa air besih bagi area industri, area bisnis maupun pemukiman penduduk di wilayah operasional, meliputi Jakarta Timur, sebagian Jakarta Pusat dan Jakarta Utara. Populasi dalam penelitian ini adalah seluruh meter reader dan administrator yang menggunakan sistem informasi SBRS pada perusahaan tersebut berjumlah total 350 orang.
Sampel merupakan bagian atau sejumlah cuplikan tertentu yang diambil dari suatu populasi dan diteliti secara rinci. Kuesioner yang disebarkan kepada para responden sebanyak 120 responden. Responden yang akan mengisi kuesioner adalah karyawan atau pemakai Spot Bill Reading System (SBRS) di kantor yang berupa website SBRS, dan pencatat meter (meter reader) yang bekerja langsung di lapangan bertemu langsung dengan pelanggan.

Teknik pengambilan sampling dalam penelitian ini adalah convenience sampling, maksudnya mengambil sampel yang sesuai dengan ketentuan atau persyaratan sampel dari populasi tertentu yang paling mudah dijangkau atau didapatkan. Misalnya yang terdekat dengan tempat peneliti berdomisili.

Teknik pengumpulan data menggunakan kuesioner yang disebarkan kepada 120 responden dan akan di analisa menggunakan tool Program Stastical Program for Social Science (SPSS) versi 17.0.

Variabel dalam penelitian ini terdapat dua variabel yaitu variabel bebas (independent) dan variabel terikat (dependent). Untuk variabel bebas adalah Kemudahan Penggunaan $\left(\mathrm{X}_{1}\right)$, Akurasi Data $\left(\mathrm{X}_{2}\right)$ dan Validasi Data $\left(\mathrm{X}_{3}\right)$. Sedangkan untuk variabel terikat adalah Kinerja Operasional Perusahaan (Y).

Desain penelitian ini akan dianalisa apakah terdapat pengaruh dari implementasi Spot bill reading system terhadap peningkatan kinerja operasional perusahaan.

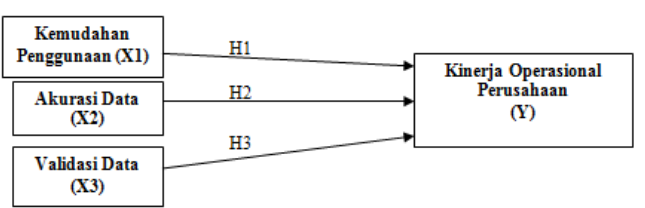

Gambar 2. Desain penelitian.

Dalam penelitian ini analisa data yang akan digunakan adalah Regresi Liniear Berganda, digunakan untuk menganalisis pengaruh antara implementasi Spot bill reading system (SBRS) meliputi kemudahan penggunaan, akurasi data dan validasi data terhadap peningkatan kinerja operasional perusahaan.

Dalam perhitungan akan digunakan Program Stastical Program for Social Science (SPSS) versi 17.0. Rumus untuk menghitunga regresi liniear dalam penelitian ini sebagai berikut :

$$
Y=a+\beta_{1} X_{1}+\beta_{2} X_{2}+\beta_{3} X_{3}+\varepsilon
$$

$\mathrm{Y}=$ variabel Peningkatan Kinerja Operasional

$\mathrm{a}=$ konstanta regresi berganda 
$\beta_{1}, \beta_{2}, \beta_{3}=$ koefisien regresi

$\mathrm{X}_{1}=$ variabel Kemudahan Penggunaan

$\mathrm{X}_{2}=$ variabel Akurasi Data

$\mathrm{X}_{3}=$ variabel Validasi Data

$\varepsilon=$ error (variabel bebas lain diluar model regresi)

\section{Hasil dan Pembahasan}

Dari data yang telah diperoleh dapat disimpulkan sebagai berikut :

TABEL I

KLASIFIKASI USIA RESPONDEN

\begin{tabular}{ccc}
\hline Usia & Frequency & Percent \\
\hline$\leq 20$ tahun & 17 & $14 \%$ \\
$21-30$ tahun & 76 & $63 \%$ \\
$31-40$ tahun & 27 & $23 \%$ \\
Total & 120 & $100 \%$ \\
\hline
\end{tabular}

TABEL II

KLASIFIKASI JENIS PENDIDIKAN TERAKHIR RESPONDEN

\begin{tabular}{ccc}
\hline Pendidikan & Frequency & Percent \\
\hline SMP & 13 & $11 \%$ \\
SMA/SMK & 73 & $61 \%$ \\
S1 & 34 & $28 \%$ \\
Total & 120 & $100 \%$ \\
\hline
\end{tabular}

TABEL III

HASIL KORELASI MASING-MASING VARIABEL

\begin{tabular}{ccccc}
\hline & $\begin{array}{c}\text { Kinerja } \\
\text { Operasional }\end{array}$ & $\begin{array}{c}\text { Kemudahan } \\
\text { Penggunaan }\end{array}$ & $\begin{array}{c}\text { Akurasi } \\
\text { Data }\end{array}$ & $\begin{array}{c}\text { Validasi } \\
\text { Data }\end{array}$ \\
\hline $\begin{array}{c}\text { Kinerja } \\
\text { Operasional }\end{array}$ & 1,000 & 0,773 & 0,885 & 0,743 \\
$\begin{array}{c}\text { Kemudahan } \\
\text { Penggunaan }\end{array}$ & 0,744 & 1,00 & 0,850 & 0,771 \\
$\begin{array}{c}\text { Akurasi } \\
\text { Data }\end{array}$ & 0,885 & 0,850 & 1,000 & 0,824 \\
$\begin{array}{c}\text { Validasi } \\
\text { Data }\end{array}$ & 0,743 & 0,771 & 0,824 & 1,000 \\
\hline
\end{tabular}

Berdasarkan hasil perhitungan regresi linear maka diperoleh suatu persamaan regresi liniear berganda yaitu :

$$
Y=0,795+0,271 X_{1}+0,188 X_{2}+0,361 X_{3}
$$

Pada model regresi di atas terlihat bahwa nilai koefisien regresi variabel bebas yaitu implementasi sistem informasi SBRS yang terdiri dari kemudahan penggunaan $\left(\mathrm{X}_{1}\right)$, akurasi data $\left(\mathrm{X}_{2}\right)$ dan validasi data $\left(\mathrm{X}_{3}\right)$ tersebut sama dengan konstan, maka diprediksikan variabel terikat implementasi sistem informasi SBRS tetap berpengaruh positif terhadap kinerja operasional perusahaan. Hal ini menunjukkan bahwa setiap peningkatan ataupun pengurangan faktor-faktor implementasi sistem informasi SBRS yang dilakukan, maka akan diikuti oleh pengurangan kinerja operasional perusahaan sebesar 0,795 dan sebaliknya.

Nilai konstanta regresi (a) $=0,795$ berarti jika tidak ada perubahan atas variabel-variabel bebasnya, maka peningkatan kinerja operasional perusahaan adalah sebesar nilai konstanta yaitu sebesar 0,795. Nilai koefisien regresi $X_{1}$ sebesar 0,271 yang berarti jika kemudahan penggunaan $\left(\mathrm{X}_{1}\right)$ berubah sebesar 1 satuan maka akan diikuti oleh perubahan kinerja operasional (Y) sebesar $21,7 \%$. Nilai koefisien regresi $X_{2}$ sebesar 0,188 yang berarti jika akurasi data $\left(\mathrm{X}_{2}\right)$ berubah sebesar 1 satuan maka akan di ikuti oleh perubahan kinerja operasional (Y) sebesar 18,8\%. Nilai koefisien regresi $\mathrm{X}_{3}$ sebesar 0,361 yang berarti jika validasi data $\left(\mathrm{X}_{3}\right)$ berubah sebesar 1 satuan maka akan di ikuti oleh perubahan kinerja operasonal (Y) sebesar 36,1\%.

\section{Kesimpulan}

Dari penelitian yang telah dilakukan, diketahui bahwa peningkatan kinerja operasional perusahaan PT.XYZ dipengaruhi salah satunya dilakukannya implementasi sistem informasi Spot bill reading system (SBRS) yang dalam penelitian ini dituangkan pada poin kemudahan penggunaan, akurasi data dan validasi data. Untuk kemudahan penggunaan berpengaruh secara langsung pada bagian dari kinerja operasional yaitu timeless \& need supervision.

Sedangkan untuk akurasi data berpengaruh langsung pada bagian dari kinerja operasional yaitu quality. Sedangkan untuk validasi data berpengaruh langsung pada bagian dari kinerja operasional yaitu quantity seperti yang telah dijelaskan di bab sebelumnya. Ketiga hipotesis tersebut yang telah diterima dan terbukti signifikan berpengaruh terhadap peningkatan kinerja operasional perusahaan.

Untuk dapat melihat perbandingan sistem informasi yang serupa dengan SBRS di tempat lain, telah disimpulkan dalam tabel berikut :

TABEL V

PERBANDINGAN AUTOMATIC METER READING SYSTEM

\begin{tabular}{lll}
\hline Sistem AMR & \multicolumn{1}{c}{ Lokasi } & \multicolumn{1}{c}{ Keterangan } \\
\hline $\begin{array}{l}\text { Spot bill } \\
\text { reading } \\
\text { system } \\
\text { BOOT Basic }\end{array}$ & $\begin{array}{l}\text { Jakarta, } \\
\text { Indonesia }\end{array}$ & $\begin{array}{l}\text { Sistem pembacaan } \\
\text { meter air dan } \\
\text { pencetakan tagihan. }\end{array}$ \\
& INDIA & $\begin{array}{l}\text { Sistem pembacaan } \\
\text { meter air dan kualitas } \\
\text { air (ph) }\end{array}$ \\
$\begin{array}{l}\text { Bill On Spot } \\
\text { System }\end{array}$ & PESU, & $\begin{array}{l}\text { Sistem pembacan } \\
\text { meter air dan penagihan } \\
\text { on the spot. }\end{array}$ \\
$\begin{array}{l}\text { The Meter } \\
\text { Reading } \\
\text { Terminal } \\
\text { (MRT) }\end{array}$ & Mumbai & $\begin{array}{l}\text { Sistem pembacan } \\
\text { meter air, integrasi } \\
\text { dengan GIS. }\end{array}$ \\
\hline
\end{tabular}


Sebagaimana telah diketahui bahwa implementasi sistem informasi SBRS yang terdiri dari kemudahan penggunaan, akurasi data dan validasi data mempunyai pengaruh yang erat dan berbanding lurus terhadap kinerja operasional perusahaan. Dari hasil analisis data kuesioner dapat disimpulkan dengan tabel berikut :

TABEL IV

REKAPITULASI PENGUJIAN HIPOTESIS

\begin{tabular}{llll}
\hline Hipotesis & Hasil Hitung & Kesimpulan & Keterangan \\
\hline H1 & $\mathrm{F}_{\text {hitung }}>\mathrm{F}_{\text {tabel }}$ & Diterima & Signifikan \\
& $272,179>3,92$ & & \\
H2 & $\mathrm{F}_{\text {hitung }}>\mathrm{F}_{\text {tabel }}$ & Diterima & Signifikan \\
& $368,186>3,92$ & & \\
H3 & $\mathrm{F}_{\text {hitung }}>\mathrm{F}_{\text {tabel }}$ & Diterima & Signifikan \\
& $323,087>3,92$ & & \\
\hline
\end{tabular}

Saran yang dapat penelitian ini berikan adalah sebagai berikut: Perlu dilakukan penelitian lebih lanjut dengan variabel berbeda. Contoh dari variabel yang dapat digunakan adalah saranaprasarana perlengkapan, kepuasan pelanggan terhadap pelayanan.

Penelitian dapat dilakukan dalam ruang lingkup yang lebih luas, tidak hanya pada implementasi sistem informasi SBRS saja tetapi juga pada sistem pembelajaran atau training yang dilakukan untuk karyawan baru, prosedur yang telah ditentukan sehingga diharapkan peneliti selanjutnya dapat melengkapi kekurangankekurangan tersebut.

Perlu adanya pengembangan lebih lanjut dari sistem informasi Spot bill reading system (SBRS), pengembangan dapat mengikuti yang telah dimiliki oleh sistem Automatic Meter Reading (AMR) di negara lain seperti integrasi data dengan sistem Geographic Information System (GIS) sehingga dapat melakukan pemetaan penyebaran pelanggan atau pemetaan daerah rawan kerusakan atau tindak kriminal dari penyediaan air bersih.

Dapat juga pengembangan untuk dapat menggunakan peralatan untuk sensoric water quality sehingga kualitas air dapat terjaga dan dapat segara ditangani apabila ada kebocoran atau pencemaran air bersih. Dengan integrasi data dengan peralatan yang dapat mendeteksi pengukuran tingkat keasaman $(\mathrm{pH})$ air dan kadar kandungan yang terkandung dalam air tersebut.

\section{Referensi}

[1] J. Salman, Kepercayaan Terhadap Teknologi Sistem Informasi Baru dalam Evaluasi Kinerja Individual. Kumpulan Materi Simposium Nasional Akuntansi VIII Solo, 15-16 September 2006.

[2] E. Wirjono, Pengaruh Kepercayaan dan Umur Terhadap Kinerja Individual Dalam Penggunaan Teknologi Informasi. Journal Fakultas Ekonomi. Universitas Atma Jaya Jogyakart, 2005.

[3] P. Zelbt, K. Green, V. Sower, Impact of RFID Technology Utilization on Operational Performance, 2010.

[4] M. Busi, U. Bititci, Collaborative Performance Management : Present Gaps and Future Research. International Journal of Productivity and Performance Management Vol. 55 No.1 pp.7-55, 2006.

[5] C. Dharma, Analisis Pengaruh Penerapan Sitem Manajemen Mutu ISO:9001:2000 Terhadap Peningkatan Kinerja pada PT. Jasa Raharja (Persero) Cabang Sumatera Utara. Universitas Sumatera Utara, 2007.

[6] F. Constantianus, B. Suteja, Analisa dan Desain Sistem Bimbingan Tugas Akhir Berbasis Web dengan Studi Kasus Fakultas Teknologi Informasi. Universitas Kristen Maranatha. 2005.

[7] M. Feng, M.Terziovski, D. Samson, The Relationship of ISO 9001:2000 Quality System Certification With Operational and Business Performance. Journal of Manufacturing Technology Management. Vol.19 No.1 pp.22-37. 2008.

[8] Y. Choi, S. Lee, J. Kim, Effect of IT Knowledge and mediaselection on operational performance. Small Business Economics, Vol 32. Pp.241-257, 2009.

[9] V. Venkatesh, H. Bala, T.Sykes, Impact of Information and Communication Technology Implementations on Employee's Jobs in Service Organizations in India:A multiMethod Longitudinal Field Study. Production and Operations Management. Vol.19 Oct 2010 pp.591-631. 